\title{
Improving Lesson Plan Models Using Online-Based in the New Normal Era
}

\author{
Firman Edi' ${ }^{1}$, Ambiyar ${ }^{2}$, Unung Verawardina ${ }^{3}$, Samsir ${ }^{4}$, Ronal Watrianthos ${ }^{4}$ \\ ${ }^{1}$ Institut Teknologi Batam \\ ${ }^{2}$ Universitas Negeri Padang \\ 3IKIP PGRI Pontianak \\ ${ }^{4}$ Universitas Al Washliyah Labuhanbatu \\ ronal.watrianthos@gmail.com
}

\begin{tabular}{ll}
\hline Article History & Received : January $9^{\text {th }} 2021$ \\
& Revision : February $13^{\text {th }} 2021$ \\
& Publication : March 30 3021
\end{tabular}

\begin{abstract}
The COVID-19 pandemic has changed human life dramatically. The new standard pushes digital technology to become part of the educational system at an accelerated growth level. This study is meant to build an online-based lesson plan model as a learning development in the new normal era. The research method uses a descriptive comparison by observation, interviews, and literature analyses. Results have demonstrated that the development of an online learning plan model for learning tools leads to potential learning systems. The challenges encountered include the lack of capability of human resources to operate online tools, the limited technology, and the challenge of adapting learning tools to the curriculum's objectives. The online learning planning model can be applied with the government, schools, and teachers' assistance. This research aims to propose the development of online-based lesson plan models as learning technologies in the new normal era. This model's development needs to be researched further because it is used during pandemics and becomes the primary method in education in the future.
\end{abstract}

Keywords: COVID-19, New Normal, Lesson Plan, Online Learning

\section{INTRODUCTION}

The term 'the new normal' has been debated since the COVID-19 pandemic. World Health Organization's (WHO) demands countries move towards a new-normal adaptation phase so that social and economic life can continue (Dziuban et al., 2018). This transition leads to behavioral changes so that you can continue your habits during the pandemic (Xinhua, 2020). The absence of a vaccine causes people to adapt to new habits to deter the pandemic's outbreak. WHO has provided a new standard protocol for each region (Frieden, 2020).

Implementing the new normal has an impact on the education sector because it hinders face-to-face teaching and learning practices (Ferrel \& Ryan, 2020). It has prompted educational institutions to stop teaching and studying both at school and on campus and replace them with online distance learning systems (Watrianthos, 2020). The use of information technology is becoming a critical factor in the new- 
normal era. They also switch and virtually rely on digital technology, not just education, business, entertainment, or sports.

Since mid-March 2020, the Indonesian government has adopted a strategy of studying and working from home through online learning through the Ministry of Education and Culture. The major problem is the inadequate perception of this strategy by the teaching staff, particularly students. The insufficient ability to sustain instruments and media and network access and the high cost of accessing the internet was another obstacle. Simultaneously, this method is an integral part of the introduction of online learning (Windhiyana, 2020).

The outbreak of a pandemic has prompted the Indonesian education system to accelerate adapting to the needs of this digital era. Apart from implementing online learning, it is interesting to develop lesson plans for online-based educational materials. The lesson plan is intended to increase the quality and efficacy of graduate skills by paying attention to the growth of new technologies and society's needs in the modern global age (Anggraeni \& Akbar, 2018).

In the Indonesian education system, the 2013 curriculum (K.13) has qualifying criteria for graduate competencies that include knowledge, behaviors, and skills. Any student must be able to learn these skills and develop their skills (Harini, 2018). The lesson plan is an essential part of teaching, consisting of several aspects: goals, objectives, activities, media, and assessment. Teachers will use lesson plans to interpret them as a guide to what students need to do and do it successfully through class instruction (Coenders \& Verhoef, 2019).

The value of designing online lesson plans must be focused on a commitment to strengthen teachers' digital literacy skills. Internet use is a valuable source of knowledge as an alternative learning tool. The internet will inspire students, make teaching more fun, and encourage critical lessons to differ. Online learning has consequences of deciding the appropriate application or web for planning lessons and modifying the lesson plans. This can be achieved by drawing up online lesson plans or changing lesson plans used in conventional classes (Harasim, 2012).

In the meantime, the literacy skills of Indonesian teachers and students are generally still very poor. This is indicated by the number of the Ministry of Education and Culture (Kemdikbud) Indonesian National Evaluation Program (INAP), the reading capacity of 46.83 percent of Indonesians is still deemed to be lacking (Alim, 2019). Meanwhile, Indonesian students' proficiency scores in reading, mathematics, and science in 2018 were lower than similar measurements three years earlier. Global measurement results for students aged 15 showed that the average score for Indonesian students was 371 in reading, 379 in mathematics, and 396 in science for math and science skills. In the previous PISA, Indonesian students recorded higher averages for all fields in 2015, namely 397, 386, and 403 for reading, math, and science skills (Harususilo, 2019). 
From the PISA report, it is known that the low quality of teachers and disparities in the quality of education in Indonesia is thought to be the main causes of poor student literacy skills in general. Another reason, I think, is that the School Literacy Movement has failed to improve the quality of student literacy. The study results of the RISE program - The SMERU Research Institute predict that the average reading ability of Indonesian students will only be equivalent to the average ability of students in OECD countries in 2090 if there are no serious efforts to improve the quality of education in Indonesia (Harususilo, 2019).

Digital literacy helps deal with information from many digital sources that are continually changing due to the media convergence phenomena. Teachers must be able by the educator era 4.0 to improve their skills sustainably with science and technology. In the Industrial 4.0 era, learning creativity is the most important key to producing skilled learners in the 21st century. The results of a survey study by the National for Information Technology and Communication Education and Culture (Pustekkom) showed that $40 \%$ of teachers are ready for information and communication technology (ICT). In comparison, the other $60 \%$ cannot change in the modern world. It proves that teachers need to improve their awareness and imagination in the digital literacy learning process.

Teachers must pay attention to elements of the description of lesson activities in online lesson plans, such as internet usage, the summary of lesson plans, and the opportunity to use interactive material. This study aims to integrate learning content with a digital-based framework into online lesson plans. It is a planning model to help teachers develop simple web learning that allows them to search, select, order, and quickly gather learning content relevant to the topic they want to teach.

\section{METHOD}

The author uses a comparative analytical framework to provide an overview of the gaps between lesson plans made for conventional and online learning approaches. In an online learning approach, the learning process is not entirely online, but there is an equal division between face-to-face and online courses (Moore et al., 2011). Through observation, interviews, and literary analyses, data collection methods offer a complete understanding of how students develop online learning plans based on academic requirements research and technical advances (Gallego \& Topaloglu, 2019).

This study's main concern is the online mid-lesson plan, taking into account that a face-to-face method in the class is also needed for the learning process. The lesson plan applies to the 2013 curriculum, which is structured for one or more meetings to design a syllabus to gain Basic Competence (BC) (Wiyanarti \& Holilah, 2020). Figure 1 below shows the structure for planning an online lesson plan. 


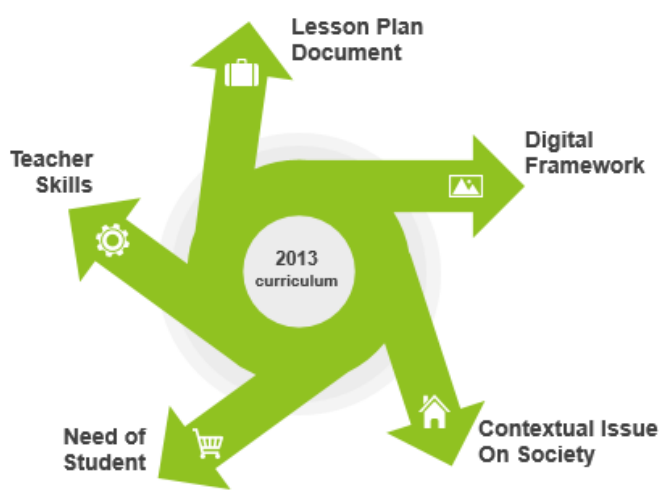

Fig. 1 Framework for the Development of an Online Lessons Plan

Based on Figure 1, the 2013 curriculum is the driving spirit in creating the lesson plan. The study plan paper is organized based on a mapping of Core Competencies with Basic Knowledge and skills (Pasaribu et al., 2020). A significant feature of an online-based study plan is that they use a digital system to manage content for the lesson plan, use digital technology as a medium, work on online-based activities, and other aspects. Similarly, teachers' expertise in using new technologies and paying attention to the needs of students who have developed online learning. Finally, the development of subjects reflects on contextual problems in the culture, in particular the digital community and the issues that come with it (Wiyanarti \& Holilah, 2020).

\section{Lesson Plan Document}

The lesson plan components are supposed to refer to the lesson plan guidance set out by the Ministry of Education and Culture. The elements include (1) school identification, (2) topic/sub-theme identity, (3) class/semester, (4) topic matter, (5) time allocation, (6) lesson goals, (7) basic skills and metrics, (8) teaching tools, (9) teaching strategies, (10) lesson materials, (11) lesson resources, (12) lesson measures and (12) evaluation.

\section{Digital Framework}

A distinguishing characteristic of the online learning program is the use of facets of technology-based expertise as learning goals and a range of interactive applications in instructional materials, media, and assessment tools. It also designed a teleconference learning process using SPADA, Webinars, internal school websites, or other websites that support it.

\section{Contextual Issue on Society}

The PISA results (Program for International Student Assessment) indicate that the direction of the world of education is no longer to countries in the European region but has shifted to countries in the Asian region, such as China and Singapore. Unfortunately, Indonesia is experiencing stagnation, even decreasing quality. The latest PISA study results show that Indonesia is only able to occupy the sixth position of the sixty-five PISA participating countries in the mathematics category. This has become a contextual issue in society so that the government through the ministry of 
education seeks to improve Indonesian education's competitiveness through curriculum development in 2013.

\section{Need of Students}

The fundamental principle of designing a learning plan must be based on an interpretation of the student's interests. Examination of needs as an initial step in the preparation of school services needs to be distinguished. To plan the methods used to gather knowledge about students' needs, this needs review is done.

\section{Teachers Skills}

Teachers must be able to act as designers (planners), implementers (implementers), and evaluators (assessors) of learning activities. The teacher is the most dominant factor because it is in the teacher's hands that successful learning can be achieved. Teacher obliged to develop a complete learning plan and systematically so that learning takes place in an interactive, inspirational, fun, challenging, motivating students to participate actively, and provides sufficient space for initiative, creativity, and independence according to the talents, interests, and physical and psychological development of students.

\section{Data Objects}

This study uses School Action Research (SAR) to assess the implications of the action and test its consequences. The research results are then followed up in the form of an adjustment of the first action (cycle) to provide full information on the effect of the activities carried out. Based on the data gathered, this study would be effective if teachers can build a lesson plan based on 11 elements and 35 metrics with an average score of 90 . The grades in this group are calculated by scores of 90-100 (very good), 80-90 (good), 65-79 (enough), 55-45 (less) and < 55 (lower).

\section{RESULTS AND DISCUSSION}

A distinguishing aspect of the online-based lesson plan is incorporating components of expertise using technology as teaching goals and the use of various multimedia applications of educational materials, media, and assessment tools. The use of smartphones is solved by technical and technology constraints since nearly everybody has them (Syawaluddin et al., 2020). Teachers and students can use Internet-connected computing computers or laptops, and they can also use tablets and smartphones that operate anywhere and at any time.

The main issue is the ability of the teacher to use the device. During the new normal age, online-based learning is new in Indonesia, so there needs to be continuous online learning implementation. Technically, Figure 2 below shows the online-based lesson plan. 


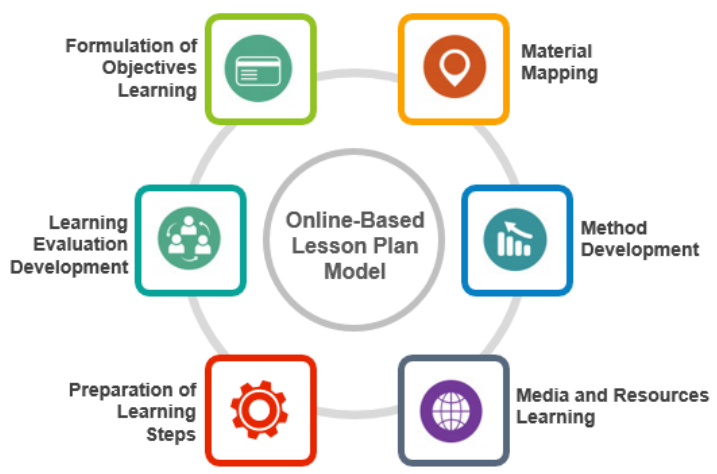

Fig. 2 Online-Based Lesson Plan Compilation

Teachers should use operational phrases that encourage students to think, be innovative and act wisely in integrating subject matter mastery with digital technology, along with contextual issues, in Figure 1 of the Framework for Developing Online-Based Lessons Plans. The goals of the lessons are to take into account the knowledge of study content and the willingness of students to run the website operate the website. The preparation of the learning plan needs to pay attention to aspects of attitudes, including discipline, honesty at work, reliable internet reference sources, anti-plagiarism, and others.

Mapping learning materials include facts, theories, values, and reasonable procedures following the lesson indicators' development. Contextual content is linked to problems that have arisen in the digital age of the social environment. Examples include social media use, cyberbullying, cybercrime, game-related mental illnesses, etc. Mapping material needs to include elements of the discussion that encourage students to search the internet independently. In material mapping, the teacher individually packed attractive descriptions in hard copy and in soft copy that can be accessed online in the form of PPT materials, PDF files, and video tutorials.

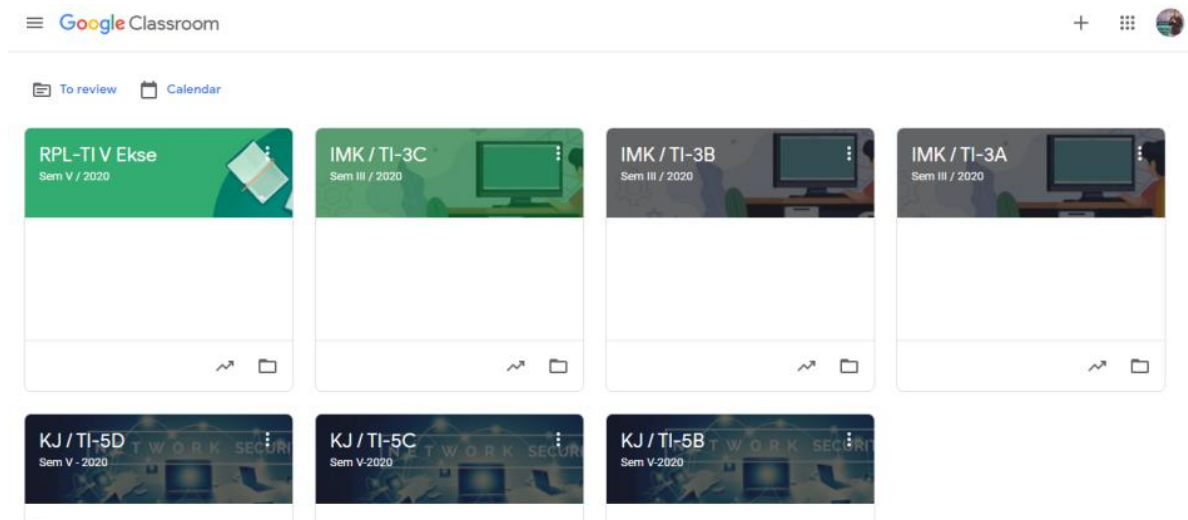

Fig. 3 Online-Based Lesson Using Google Classroom

The formulation of learning approaches, models, methods, and techniques needs to have particular attributes in online learning plans such as Research, Technology, and Society (STS), web-based learning models, project-based lessons, problem- 
based learning, and others. In designing online-based lesson plans, the next part is learning materials and learning media, the main keys. Teachers must use the internet, which is completely equipped for learning activities in online-based lesson plans. Besides, as shown in Figure 3, teachers may also use other web learning, such as Moodle, Google Classroom, SPADA, etc.

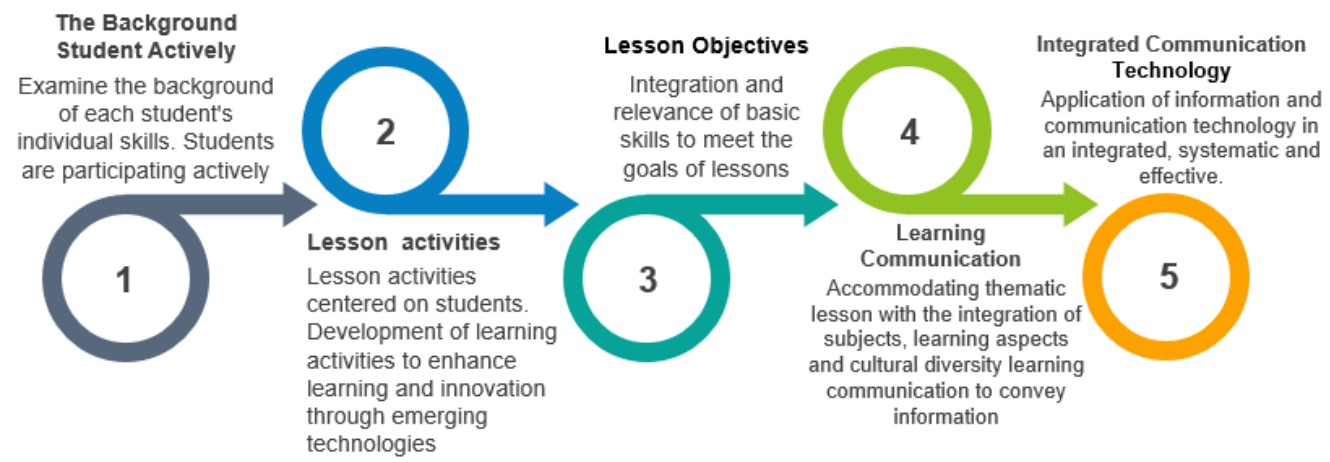

Fig. 4 the Development of Online-Based Lesson Plan Steps

The development of an online step-by-step lesson plan requires the following principles as shown in Figure 4. This online learning is a type of development in learning practices that aims to enable teachers, particularly in the new normal era that requires online learning, to adjust learning activities to follow the times. It should be emphasized, though that online lessons are just as additional because educating is the development of character learned in the classroom by face-to-face experiences.

Overall, the online lesson plan presents the benefit of attracting attention and encouraging students to prepare in line with technology advances. It allows students the ability to discuss situations where a pandemic exists. Online learning plans will build student independence and train students to play an active role in real life. Future students have the knowledge, attitudes, and skills that are relevant to the new normal era.

\section{CONCLUSION}

It is concluded that to address the demands of designing learning programs in the modern normal age, online-based lesson plans can be introduced as a development. Teachers can use multimedia devices remotely to have a balanced ratio of classroom and online-based face-to-face classes. With school funding, new learning resources, teachers' abilities to operate digital platforms, and student needs, online-based lesson plans will take place. The main keys to the success of online-based learning programs are the capability and ability of teachers, students, schools, parents and the community. 


\section{REFERENCES}

Alim, M. (2019). Pengamat: Literasi Guru dan Siswa Indonesia Masih Lemah. Jurnas.Com. http://www.jurnas.com/artikel/58628/Pengamat-Literasi-Gurudan-Siswa-Indonesia-Masih-Lemah/

Anggraeni, P., \& Akbar, A. (2018). KESESUAIAN RENCANA PELAKSANAAN PEMBELAJARAN DAN PROSES PEMBELAJARAN. Jurnal Pesona Dasar, 6(2). https://doi.org/10.24815/pear.v6i2.12197

Coenders, F., \& Verhoef, N. (2019). Lesson Study: professional development (PD) for beginning and experienced teachers. Professional Development in Education, 45(2), 217-230. https://doi.org/10.1080/19415257.2018.1430050

Dziuban, C., Graham, C. R., Moskal, P. D., Norberg, A., \& Sicilia, N. (2018). Blended learning: the new normal and emerging technologies. International Journal of Educational Technology in Higher Education, 15(1), 3. https://doi.org/10.1186/s41239-017-0087-5

Ferrel, M. N., \& Ryan, J. J. (2020). The Impact of COVID-19 on Medical Education. Cureus. https://doi.org/10.7759/cureus.7492

Frieden, T. (2020). A New Normal With COVID-19: The Next Steps We Must Take. Thinkglobalhealth.Org. https://www.thinkglobalhealth.org/article/newnormal-covid-19-next-steps-we-must-take

Gallego, G., \& Topaloglu, H. (2019). Online Learning. In International Series in Operations Research and Management Science. https://doi.org/10.1007/978-14939-9606-3_10

Harasim, L. (2012). Learning Theory and Online Technologies. In Learning Theory and Online Technologies. Routledge. https://doi.org/10.4324/9780203846933

Harini, S. (2018). IMPLEMENTASI PENDIDIKAN KARAKTER DALAM KURIKULUM 2013. SOSIOHUMANIORA: Jurnal Ilmiah Ilmu Sosial Dan Humaniora, 4(2). https://doi.org/10.30738/sosio.v4i2.2982

Harususilo, Y. E. (2019). Skor PISA Melorot, Disparitas dan Mutu Guru Penyebab Utama.

Edukasi.Kompas.Com. https://edukasi.kompas.com/read/2019/12/07/13524501/skor-pisamelorot-disparitas-dan-mutu-guru-penyebab-utama?page=all

Moore, J. L., Dickson-Deane, C., \& Galyen, K. (2011). e-Learning, online learning, and distance learning environments: Are they the same? The Internet and Higher Education, 14(2), 129-135. https://doi.org/10.1016/j.iheduc.2010.10.001

Pasaribu, E. Z., Ritonga, M. W., Watrianthos, R., \& Hidayah, M. (2020). Pengembangan Lembar Kerja Siswa Matematika Berbasis Model Discovery Learning Terhadap Kemampuan Pemahaman Konsep Matematis Siswa Kelas Xi Di Sma Negeri 1 Rantau Selatan. MAJU, 7(2), 212-220.

Syawaluddin, F. A., Yana, R. F., Siagian, T. N., \& Watrianthos, R. (2020). Efektifitas Media ICT dalam Meningkatkan Motivasi Belajar dan Hasil Belajar Pendidikan Agama Islam Kelas X SMK Swasta Siti Banun Rantauprapat Kabupaten Labuhan Batu. Pena Cendikia, 2(1).

Watrianthos, R. (2020). Analisis Pembelajaran Daring di Era Pandemic Covid-19. In Merdeka Kreatif di Era Pandemi Covid-19: Suatu Pengantar (Vol. 1). Green Press.

Windhiyana, E. (2020). DAMPAK COVID-19 TERHADAP KEGIATAN PEMBELAJARAN ONLINE DI PERGURUAN TINGGI KRISTEN DI INDONESIA. Perspektif Ilmu Pendidikan, 34(1), 1-8. https://doi.org/10.21009/PIP.341.1 
Wiyanarti, E., \& Holilah, M. (2020). The Innovation of Online-Based Social Studies Lesson Plan Models to Face the Industrial Revolution 4.0. Proceedings of the International Conference On Social Studies, Globalisation And Technology (ICSSGT 2019). https://doi.org/10.2991/assehr.k.200803.003

Xinhua. (2020). WHO says living with COVID-19 to be new normal as global cases top $10 \mathrm{mln}$. Xinhuanet.Com. http://www.xinhuanet.com/english/202006/30/c_139176146.htm 